\title{
ПРО ВИКОНАННЯ У 2020 р. ПРОГРАМИ СПІЛЬНОЇ ДІЯЛЬНОСТІ НАЦІОНАЛЬНОЇ АКАДЕМІЇ НАУК УКРАЇНИ ТА НАЦІОНАЛЬНОЇ АКАДЕМІЇ ПЕДАГОГІЧНИХ НАУК УКРАЇНИ НА 2020-2022 РОКИ
}

Наукова доповід ь на засіданні Президії НАПН України 17 грудня 2020 р. https://doi.org/10.37472/2707-305X-2020-2-2-2-5

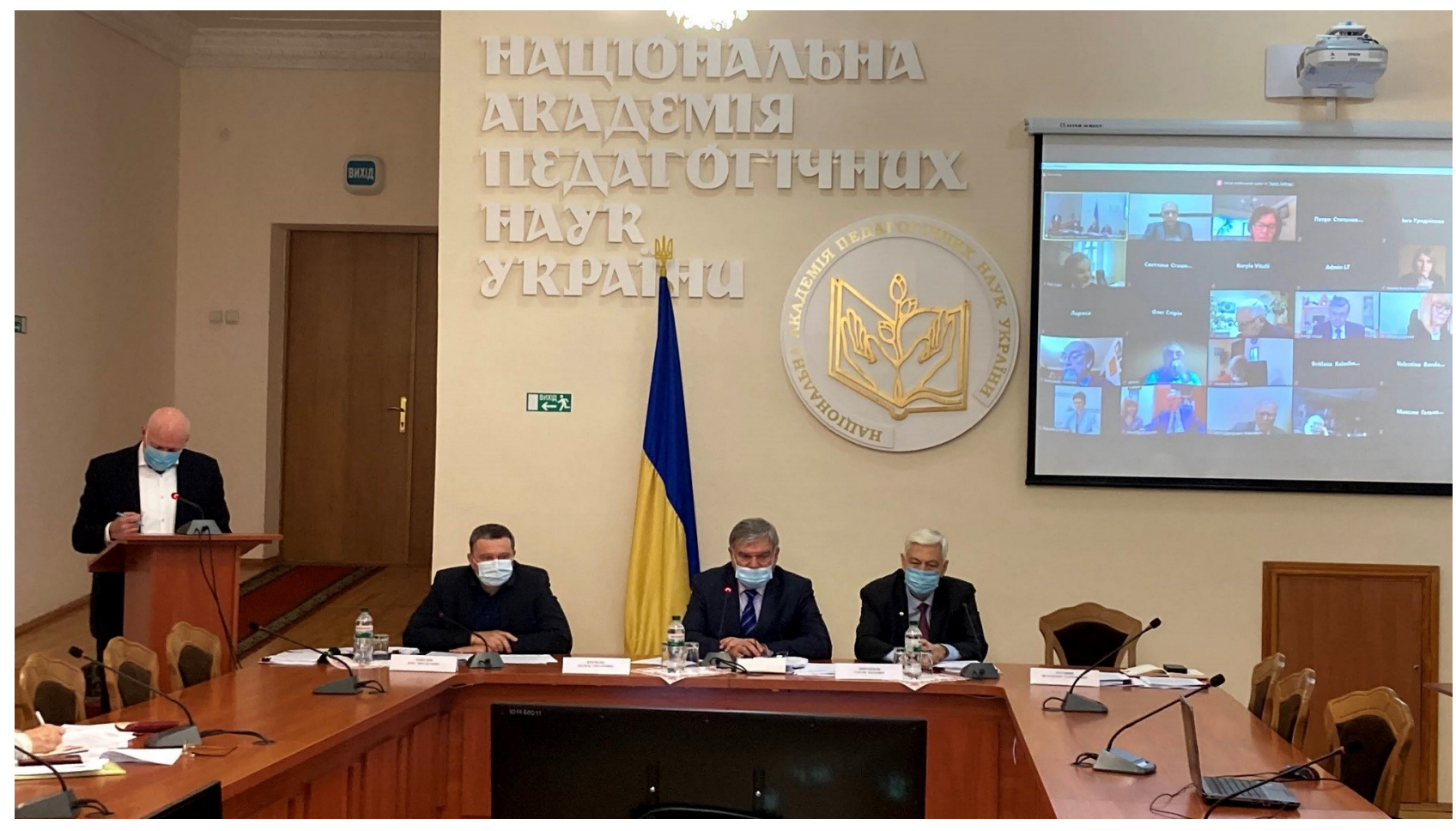

KPEMEHЬ

Василь Григорович доктор філософьських наук, профресор, дійсний член (академік) НАН України і НАПН України, президент Начіональної академії педагогічних наук України, м. Київ, Україна (iD)
лУгОВиЙ

Володимир Іларіонович доктор педагогічних наук, профессор, дійсний член (академік) НАПН України, перший віцепрезидент Національної академії педагогічних наук України, м. Київ, Україна
ТОПУЗОВ

Олег Михайлович доктор педагогічних наук, профресор, дійсний член (академік) НАПН України, віче-президент Національної академії педагогічних наук України, м. Київ, Україна

\section{iD $\triangle$}

РЕГЕЙЛО Ірина Юріївна

доктор педагогічних наук, старший науковий співробітник, начальник науково-організаційного відділу anaрату Президії Начіональної академії педагогічних наук України, м. Київ, Україна

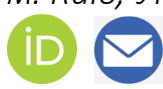

БАЗЕЛЮК Наталія Валеріївна

кандидат педагогічних наук, заступник начальника науковоорганізаційного відділу апарату Президії Національної академії педагогічних наук України, м. Київ, Україна 
Анотація. Представлено інформацію про виконання у 2020 р. Програми спільної діяльності Національної академії наук України та Національної академії педагогічних наук України на 2020-2022 роки. За Програмою здійснювалися погодження фундаментальних наукових досліджень НАПн України; розроблення психологічного супроводу освітньої й інших сфер діяльності; співпраця з Національним иентром «Мала академія наук України»; обгрунтування методологічних засад з питань професійного (професійно-технічного) розвитку; підготовка та підвищення кваліфікації оперативно-диспетчерського персоналу в енергетичній галузі; розвиток позашкільної освіти; підготовка наукових і навчальних видань; поповнення галузевого сегменту загальнодержавної реферативної бази даних "Україніка наукова» та УРж "Джерело»; проведення спільних науково-практичних масових заходів, зокрема у межах XVI Всеукраїнського фрестивалю науки, тощо. Окреслено питання, що потребують подальшого вирішення в рамках спільної діяльності.

Ключові слова: Програма спільної діяльності; Національна академія наук України; Національна академія педагогічних наук України; наука; освіта; педагогіка; психологія; науковий і методичний супровід освіти; розвиток інноваційної людини.

Співпраця Національної академії наук України та Національної академії педагогічних наук України об'єктивно зумовлена від самого початку функціонування НАПН України з 1992 р. Історично створення НАПН України було підтримано президентом НАН України Б.Є. Патоном. Упродовж цих років співпраця розвивалася за багатьма напрямами, зокрема це взаємне членство в академіях, участь у керівних органах, робочих групах, фестивалях науки тощо. Особливо тісне співробітництво відбувалося під час підготовки та прийняття у 2015 р. Закону України «Про наукову і науковотехнічну діяльність», що знайшло відображення у статтях 17 і 18 Закону. Нині зближення та взаємодія академій посилюються через те, що ці наукові установи залишаються потужними осередками організованої науки в Україні. Про доцільність функціонування і розвитку НАН України та національних галузевих академій наук України та їх реформування у подібний спосіб наголошено в заключному звіті незалежного європейського аудиту національної системи досліджень та інновацій України 2017 р.

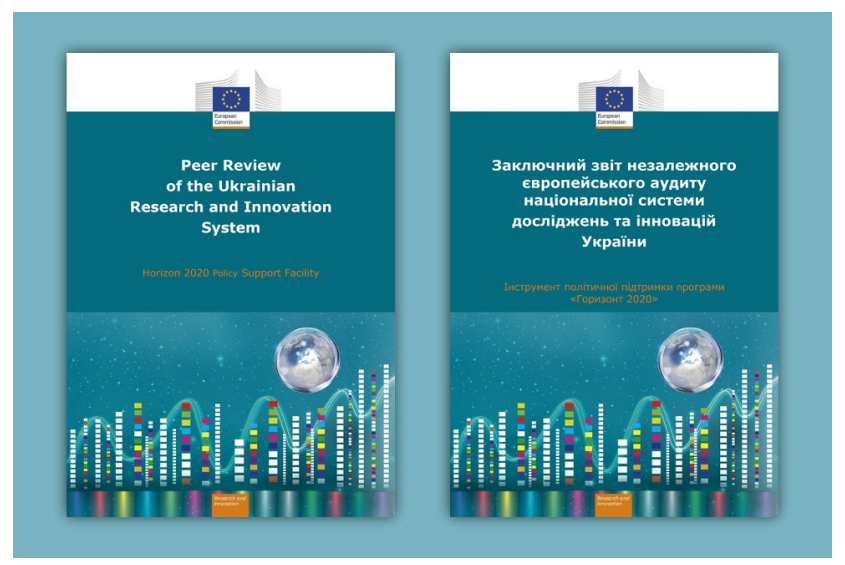

У зв'язку з цим історично важливою та епохальною подією стала Програма спільної діяльності Національної академії наук України та Національної академії педагогічних наук України на 2020-2022 рр. (далі - Програма), розроблення і

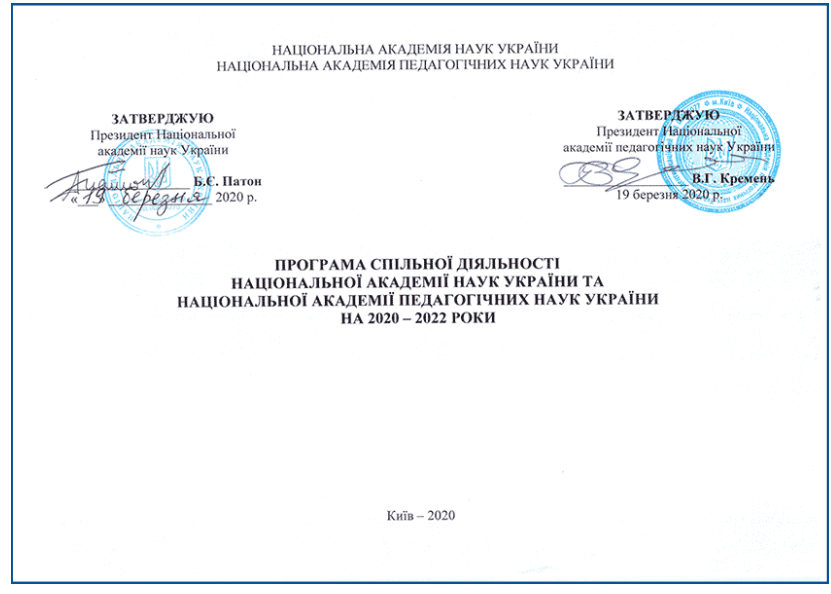

підписання якої особисто підтримали Б.Є. Патон і В.Г. Кремень. Програма підготовлена вченими обох академій та ухвалена керівництвом НАН України та НАПН України 19 березня 2020 р. Реалізація програми передбачає виконання 56 заходів, зокрема проведення спільних наукових досліджень та експериментальних розробок, підготовку наукових і навчальних видань, проведення науково-практичних масових заходів тощо.

Відповідно до статті 17 частини 2 Закону України «Про наукову і науково-технічну діяльність» щороку НАН України здійснюється погодження фундаментальних наукових досліджень НАПН України, виконання яких розпочинається у наступному році. У 2020 р. погоджено 18 тем фундаментальних наукових досліджень підвідомчих установ НАПН України, що розпочинаються у 2021 р., відповідно до актуальності та затребуваності їх тематики.

Перший рік реалізації Програми засвідчив високий евристичний та творчий потенціал цього документу, що зумовило відкриття нових аспектів досліджень, які не передбачалися до їх виконання.

Плідною виявилася співпраця НАН України і НАПН України щодо розроблення психологічного супроводу освітньої й інших сфер діяльності та його здійснення на практиці. За участю вчених Інституту кібернетики імені В.М. Глушкова НАН 
України та Інституту психології імені Г.С. Костюка НАПН України розроблено:

- основні положення психологічної складової Концепції CRM «Освіта» - створення загальноукраїнської системи багатовекторної взаємодії учасників освітньої сфери з різними рангами доступу та ефективної прицільної доставки інформації. Це дає змогу у реальному часі відслідковувати, контролювати та корегувати весь освітній процес на рівні кожного його учасника. Особливого значення це набуває в умовах природних та техногенних надзвичайних ситуацій (зокрема наслідків, пов'язаних з пандемією COVID-19), а також для реального забезпечення інклюзії;

- психологічну систему тестування підручників для Нової української школи за допомогою нейротехнологічних інструментів, які фіксують підсвідомі реакції користувачів навчальної книги на інтелектуальний продукт. Тестування допоможе психологам оцінити емоційні, мисленнєві, поведінкові прояви взаємодії користувача 3 інтелектуальними розробками. На основі отриманих даних істотно доповнюються результати експертизи підручників з використанням традиційних методів. у звітному році підготовлено протоколи дослідження, які прописують методи та процедуру тестування інтелектуального продукту з використанням нейроінтерфейсу та окулографу, адаптовано дослідницьку процедуру в умовах пандемії COVID-19, імплементовано Етичний кодекс NMSBA (Neuromarketing Science \& Business Association) у професійну діяльність дослідника навчального видання; налагоджено співпрацю 3 першою нейромаркетинговою компанією України «Neuro Psy Tech Group», яка має в своєму розпорядженні матеріальну базу для проведення тестування.

В Інституті педагогічної освіти і освіти дорослих імені Івана Зязюна НАПН України розроблено та впроваджується науковометодичне забезпечення психологічного супроводу професійноі діяльності наукових працівників з проблем активізації особистіснопрофесійного ресурсу вчених та здобувачів наукового ступеня; психологічної підтримки осіб похилого віку в процесі наукової діяльності; оволодіння науковцями конструктивними засобами подолання вікових криз на перехідних етапах професійного розвитку.

Вченими Інституту спеціальної педагогіки і психології імені Миколи Ярмаченка НАПН України у звітному році на виконання заходів Програми здійснено підбір психометричних, психологопедагогічних діагностичних методик щодо з'ясування стану психофізичного розвитку дітей раннього і передшкільного віку. Проведено ранню діагностику особливих освітніх потреб дітей за шкалою KID з виявлення типових форм поведінки дітей перших років життя, модифікованого скринінгового тест-опитувальника М-СНАТ для з'ясування ризику наявності аутизму та розладів аутистичного спектру, профілем психічного розвитку G.D. Alpern-Boll для визначення психічного розвитку дитини відповідно до віку тощо. Здійснено аналіз клінічних даних з виявлення порушень розвитку у дітей раннього та передшкільного віку.

Одним із ключових напрямів у рамках спільної діяльності є співпраця з Національним чентром «Мала академія наук України», а саме:

- проведення 3 Відділенням професійної освіти і освіти дорослих НАПН України експерименту всеукраїнського рівня "Організаційно-педагогічні умови створення і функціонування STEAMцентру» (наказ МОН України від 10 липня 2019 р. № 954) з метою вдосконалення професійної підготовки майбутніх кваліфікованих робітників з використанням інноваційних освітніх техно-

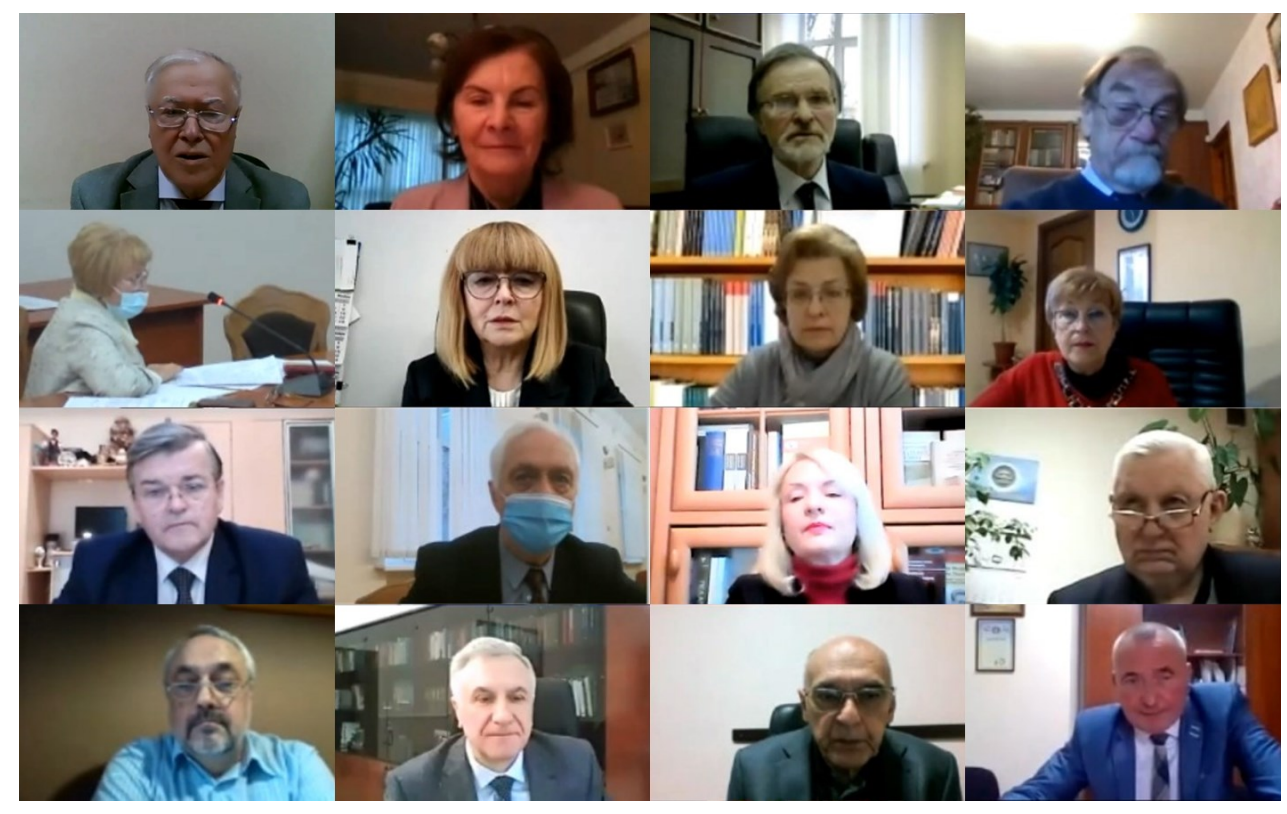


логій. Учасникам експерименту надано доступ до створених НЦ «МАН України» прикладних розробок, зокрема Віртуального STEM-центру, Всеукраїнського Інтернет-турніру із природничих дисциплін «Відкрита природнича демонстрація», Музейної планети, Віртуального музею НАН України тощо;

- розроблення з вченими Інституту обдарованої дитини НАПН України освітньої програми спеціалізованої освіти наукового спрямування для обдарованих дітей. Проєкт є основою для інтеграційних процесів між формальною і неформальною освітою, зближення освітніх систем, різних типів освітніх закладів і установ, які можуть надавати освітні послуги, сприяє створенню оптимальних умов для реалізації спеціалізованої освіти наукового спрямування та розбудови інтегрованого освітнього простору відповідних освітніх закладів;

- започаткування секції «Медіапсихологія» (Інститут соціальної та політичної психології НАПН України) для відділення хімії та біології Київської Малої академії наук;

- участь вчених Українського науковометодичного центру практичної психології і соціальної роботи у проведенні Всеукраїнського конкурсу-захисту науково-дослідницьких робіт учнів - членів Малої академії наук України, зокрема за напрямом «Психологія», у складі журі конкурсу у Львівській області та рецензуванні наукових робіт конкурсу у Харківській області;

- участь вчених НАПН України у відкритті «Музею науки».

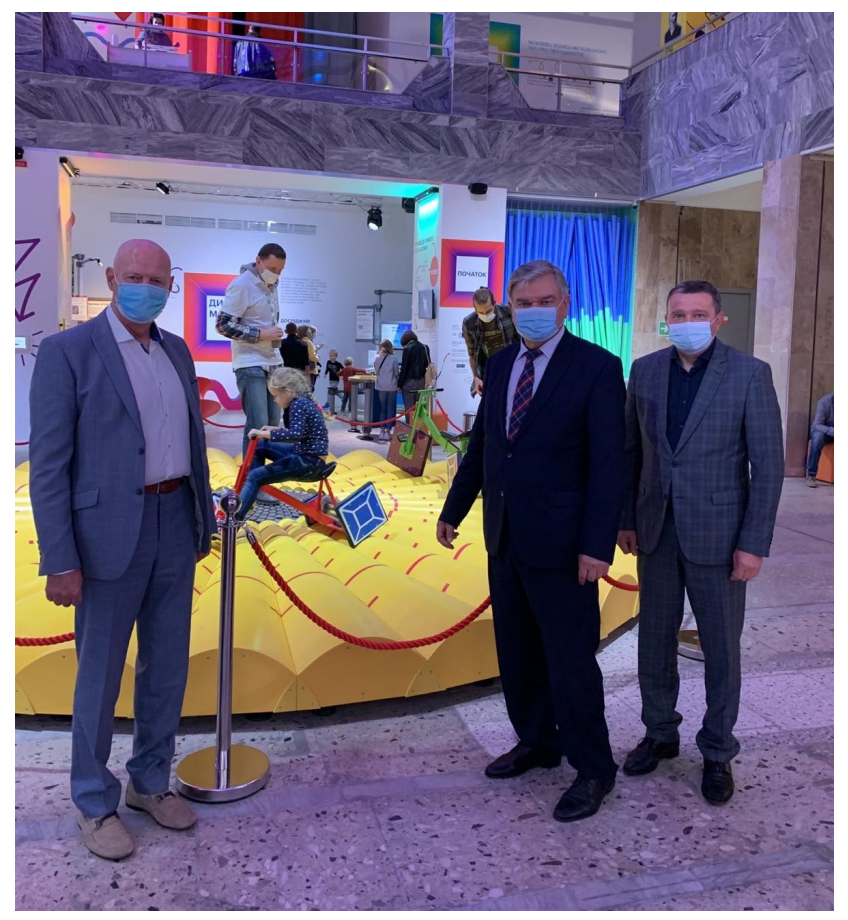

Важливим напрямом є розроблення методологічних засад з питань професійного (професійнотехнічного) розвитку. Зокрема, діяльність вчених Інституту професійно-технічної освіти НАПН України спрямовувалася на створення та обґрунтування методології вибору стратегії сталого розвитку техногенно навантажених регіонів України; підготовку електронних навчальних засобів з метою формування інформаційного освітнього середовища в системі професійної (професійно-технічної) освіти.

Успішно триває співпраця Інституту інформаційних технологій і засобів навчання НАПН України з Інститутом проблем моделювання в енергетиці імені Г.Є. Пухова НАН України щодо підготовки ma підвищення кваліфікації оперативнодиспетчерського персоналу в енергетичній галузі України. Вченими обґрунтовано важливість використання сучасних веб-орієнтованих технологій для навчання персоналу в енергетичній галузі України; описано особливості створення навчально-методичної бази для системи підготовки та підвищення кваліфікації; визначено переваги застосування розподіленого середовища для організації навчання і тренажерної підготовки оперативного персоналу за допомогою засобів моделювання режимів роботи електроенергетичних систем у віртуальному центрі; обґрунтовано навчально-методичну базу, структуру та функції віртуального науково-навчального центру.

Актуальним є практичний розвиток позашкільної освіти. Спільно з Національним ботанічним садом імені М.М.Гришка НАН України вчені Інституту проблем виховання НАПН України взяли участь у реалізації Програми «Екологічними стежками рідної України для дітей та молоді Донецької області». її результатом стало впровадження практик патріотичного виховання дітей та молоді, популяризація досвіду установ НАН України з питань збереження природно-заповідного фонду України.

Підвищенню якості освіти сприятиме спільна діяльність вчених НАН України і НАПН України при підготовці наукових і навчальних видань:

- вчені Інституту педагогіки НАПН України (М.В. Головко) та Головної астрономічної обсерваторії НАН України (І.П. Крячко) підготували підручник для 11 класу закладів середньої освіти профільного рівня «Астрономія»;

- наукові працівники Інституту педагогічної освіти і освіти дорослих імені Івана Зязюна НАПН 
України взяли участь в укладанні другого тому академічного видання "Українська фольклористична енциклопедія» у взаємодії 3 Інститутом мистецтвознавства, фольклористики та етнології імені М.Т. Рильського НАН України, підготовці рукопису монографії «Традиції та новації в світовій енциклопедистиці 2020».

Посилено співпрацю Державної науково-педагогічної бібліотеки України імені В.О. Сухомлинського 3 Національною бібліотекою України В.І. Вернадського, у рамках якої поповнюється галузевий сегмент загальнодержавної реферативної бази даних «Україніка наукова» та Українського реферативного журналу "Джерело». Зокрема, у 2020 р. підготовлено 1289 записів, 4374 рефератів трьома мовами. Здійснюється бібліометричний аудит педагогічної науки за результатами наукометричної системи «Бібліометрика української науки».

Особливе місце у виконанні заходів Програми відведено проведенню спільних з НАН України науково-практичних масових заходів - конференцій, семінарів, круглих столів, виставок тощо. Вчені НАН України і НАПН України взяли участь в організації XVI Всеукраїнського фестивалю науки у травні 2020 р. У рамках цього фестивалю вченими НАПН України заплановано і проведено близько 30 заходів, серед яких:

- міжнародні та всеукраїнські конференції: Всеукраїнська науково-практична конференція здобувачів вищої освіти і молодих учених «Наука і молодь 2020: пріоритетні напрями глобалізаційних змін», XIV Міжнародна науково-практична конференція 3 організаційної та економічної психології «Психологічне здоров'я персоналу організацій: проблеми та технології забезпечення», II Всеукраїнський тифлофорум «Освіта дітей з порушеннями зору: виклики сучасності», II Міжнародна науково-практична конференція «Актуальні проблеми технологічної і професійної освіти», X Всеукраїнські психолого-педагогічні читання, присвячені пам'яті Б.О. Федоришина «Профорієнтація: стан і перспективи розвитку», Міжнародна науково-практична конференція «Педагогічна компаративістика і міжнародна освіта 2020: глобалізований простір інновацій», IV Всеукраїнська науково-практична конференція «Особистість студента та соціокультурне середовище університету в суспільному контексті» та ін.;

- семінари, круглі столи та майстер-класи: Міжнародний семінар «Забезпечення якості підготовки докторів філософії (PhD)» (у межах проєкту «Структурована співпраця в області докторських досліджень (підготовки), підготовки з універсальних навичок та академічного письма в регіонах України», DocHub), Міжінститутський семінар $з$ кіберсоціалізації, круглі столи «Зміст формування креативності у вихованців закладів позашкільної освіти науково-технічного напряму», «Наукова молодь України в умовах міжнародних інтеграційних процесів: реалії та виклики сьогодення», науково-практичні семінари «Психологопедагогічна підтримка дитини 3 особливими освітніми потребами, що перебуває на інклюзивному навчанні», «Інноваційні компетентнісноорієнтовані технології в освіті дітей з порушеннями інтелектуального розвитку», «Діти з порушеннями слуху: ефективні технології викладання та позитивні практики», «Психолінгвістичний дефіцит: сучасні логопедичні технології виявлення задоволення мовленнєвих потреб», «Науковоінформаційний супровід модернізації та реформування освіти й науки», «Особистісні трансформації у воєнний і поствоєнний період», майстерклас «Партнерська взаємодія науковців і педагогів-практиків у формуванні просоціальної поведінки підлітків уразливих категорій» та ін.;

- книжкові виставки «Європейська освіта крок до якісного життя», «Учені Національної академії педагогічних наук України - вітчизняній науці» та ін.

У звітному році підвідомчі установи НАН України та НАПН України виступили співорганізаторами низки інших заходів, зокрема це:

- VIII Всеукраїнська науково-практична конференція молодих учених «Наукова молодь 2020», 21 жовтня 2020 р. (серед співорганізаторів - Рада молодих вчених НАН України, Рада молодих вчених Відділення ядерної фізики та енергетики НАН України, Рада молодих вчених Відділення фізико-технічних проблем енергетики НАН України, Рада молодих вчених Інституту

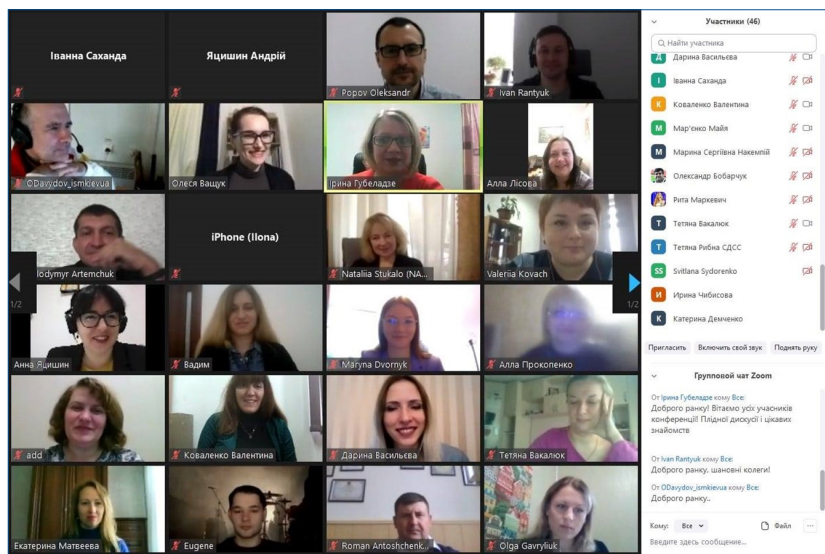


інформаційних технологій і засобів навчання НАПН України, Рада молодих вчених Інституту соціальної та політичної психології НАПН України, Рада молодих вчених Інституту проблем моделювання в енергетиці імені Г.Є. Пухова НАН України, Державна установа «Інститут геохімії навколишнього середовища НАН України», Рада молодих вчених Інституту професійно-технічної освіти НАПН України);

- вебінар «Рідномовна і багатомовна освіта у контексті сталого розвитку суспільства» до Міжнародного дня рідної мови, 19 лютого 2020 р. (серед співорганізаторів - Кафедра ЮНЕСКО «Неперервна професійна освіта XXI століття» НАПН України, Інститут літератури імені Тараса Шевченка НАН України);

- круглий стіл «Громадянсько-патріотичні ідеї Т.Г. Шевченка в соціокультурному та освітньому просторі України», 9 березня 2020 р. (Кафедра ЮНЕСКО «Неперервна професійна освіта XXI століття» НАПН України, Інститут літератури імені Тараса Шевченка НАН України);

- семінар «Екологічна складова концепції сталого розвитку: кращі практики дитячих громадських організацій та об'єднань», 26 серпня 2020 р. (Інститут проблем виховання НАПН України, Інститут географії НАН України);

- Всеукраїнська науково-практична онлайнконференція «Підтримка та супровід обдарованих учнів в сучасному інформаційно-освітньому просторі», 27 жовтня 2020 р. (Інститут обдарованої дитини НАПН України, Інститут літератури імені Тараса Шевченка, Інститут філософії імені Г.С. Сковороди, Інститут всесвітньої історії, Національний центр «Мала академія наук України» НАН України);

- ІІ Форум «Інноваційні трансформації в сучасній освіті: виклики, реалії, стратегії», 25-26 листопада 2020 р. (Інститут обдарованої дитини НАПН України, Національний центр «Мала академія наук України»);

- методологічний семінар «Голодомор в Україні у проєкції світової інформаційно-освітньої рефлексії», 3 грудня 2020 р. (Інститут проблем виховання НАПН України, Інститут історії України НАН України);

- постійно діючий міждисциплінарний науковий семінар Фонду В.М.Глушкова «Проблеми розвитку розуму і взаємодії розумних систем та їх підсистем» (за участі вчених Інституту психології імені Г.С. Костюка НАПН України) тощо.

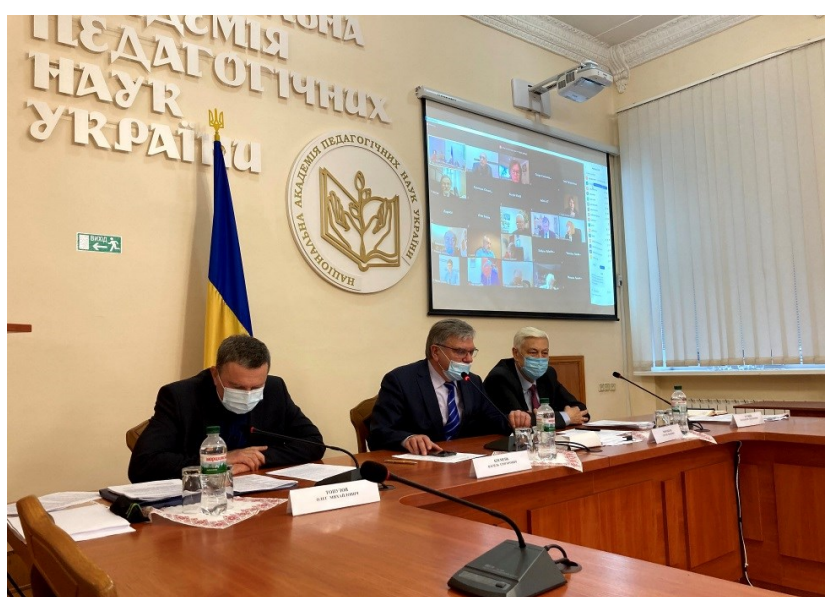

Провідні вчені НАН України та НАПН України систематично беруть участь у загальних зборах та засіданнях президій НАН України та НАПН України.

Проведено консультації вчених обох академій щодо шляхів реформування НАН України і НАПН України, вдосконалення шкільної освіти з природничо-математичних дисциплін.

Аналіз результатів виконання у 2020 р. Програми спільної діяльності Національної академії наук України та Національної академії педагогічних наук України на 2020-2022 роки засвідчує, що співпраця між вченими НАН України та НАПН України була ефективною, заплановані у Програмі заходи в основному виконано.

Водночас існує низка питань, що потребують подальшого вирішення в рамках спільної діяльності, зокрема:

- унормування проведення спільних наукових досліджень, експериментів, зокрема викладання і вивчення природничо-математичних дисциплін у школі;

- створення підручників, зокрема для природничо-математичної галузі, з проблем цифрової дидактики, штучного інтелекту;

- матеріально-технічне забезпечення, зокрема фінансування оренди апаратурних засобів;

- створення постійно діючих об'єднань (комісій) з вирішення актуальних питань організації освітньої та наукової діяльності;

- використання потенціалу українських галузевих терміносистем, досягнень прикладної лінгвістики, лексикографічних корпусів у процесі дослідницької роботи та педагогічної діяльності шляхом консультаційної, просвітницької роботи у закладах освіти, наукових установах;

- організація дистанційної психологічної підтримки, зокрема психолого-педагогічний супровід родин дітей з особливими освітніми потребами, в умовах надзвичайних ситуацій; 
- розроблення та реалізація державної політики щодо бібліотечної справи в Україні, оновлення ії нормативно-правової бази;

- розроблення дієвих механізмів використання результатів наукових досліджень, інформаційноаналітичних матеріалів та експертних висновків НАН України та НАПН України у процесі формування державної політики в галузі освіти і науки та у практичній діяльності закладів освіти, установ, організацій тощо.

\section{СПИСОК ВИКОРИСТАНИХ ДЖЕРЕЛ}

Європейська Комісія. (2017). Заключний звіт незалежного європейського аудиту національної системи досліджень та інновацій України. Інструмент політичної підтримки програми «Горизонт 2020». Короткий зміст та рекомендації щодо покращення секторальної політики. https:// doi.org/10.2777/462461
Закон України "Про наукову $і$ науково-технічну діяльність». (2015, 26 листопада). https:// zakon.rada.gov.ua/laws/show/848-19

Кремень, В.Г. (2020). Про Програму спільної діяльності Національної академії наук України та Національної академії педагогічних наук України на 20202022 роки. Вісник Національної академії педагогічних наук України, 2(1). https://doi.org/10.37472/2707305X-2020-2-1-2-3

Національна академія педагогічних наук України. (2020). Програма спільної діяльності Начіональної академії наук України та Начіональної академії педагогічних наук України на 2020-2022 роки. http://naps.gov.ua/ua/activities/research/nas/

European Commission. (2017). Peer review of the Ukrainian research and innovation system. Horizon 2020 policy support facility. Luxembourg: Publications Office of the European Union. https:// doi.org/10.2777/095726

\section{ON EXECUTING IN 2020 THE JOINT ACTIVITY PROGRAM OF THE NATIONAL ACADEMY OF SCIENCES OF UKRAINE AND NATIONAL ACADEMY OF EDUCATIONAL SCIENCES OF UKRAINE FOR 2020-2022 \\ Scientific report at the meeting of the Presidium of the National Academy of Educational Sciences of Ukraine, December 17, 2020}

Vasyl Kremen

DSc in Philosophy, Professor, Full Member (Academician) of NAS of Ukraine and NAES of Ukraine, President, National Academy of Educational Sciences of Ukraine, Kyiv, Ukraine Volodymyr Lugovyi

DSc in Education, Professor, Full Member (Academician) of NAES of Ukraine, First Vice-President, National Academy of Educational Sciences of Ukraine, Kyiv, Ukraine Oleh Topuzov

DSc in Education, Professor, Full Member (Academician) of NAES of Ukraine, Vice-President, National Academy of Educational Sciences of Ukraine, Kyiv, Ukraine Iryna Reheilo

DSc in Education, Senior Researcher, Head of the Scientific and Organizational Department, National Academy of Educational Sciences of Ukraine, Kyiv, Ukraine

Nataliia Bazeliuk

PhD in Education, Deputy Head of the Scientific and Organizational Department, National Academy of Educational Sciences of Ukraine, Kyiv, Ukraine

Abstract. The information on executing in 2020 the Joint Activity Program of the National Academy of Sciences of Ukraine and National Academy of Educational Sciences of Ukraine for 2020-2022 is presented. The following actions were carried out: coordination of basic researches of NAES of Ukraine; development of psychological support of educational and other spheres of activity; cooperation with the National Center "Junior Academy of Sciences of Ukraine"; grounding the methodological bases on professional (vocational) development; pre-service and in-service training of the operational and dispatching personnel in the energy sector; implementing the out-of-school education; preparing the scientific and training publications; filling the branch segment of the national abstract database "Ukrainika naukova" and Ukrainian abstract journal "Dzherelo"; conducting joint scientific and practical events, in particular within the 16th All-Ukrainian Science Festival, etc. The issues that need a further solution in a joint activity are outlined.

Keywords: Joint Activity Program; National Academy of Sciences of Ukraine; National Academy of Educational Sciences of Ukraine; science; education; pedagogy; psychology; scientific and methodological support of education; innovative person development. 